\title{
Teaching and Learning in Classroom Based on Design Thinking
}

\author{
Min Li \\ Business School, Shandong University of Technology \\ Zibo, China \\ Email: 508429449 [AT] qq.com
}

\begin{abstract}
To address complex problems, design thinking is highly valuable because it offer a mindset and collection of strategies to systematically gather, analyze, and utilize data to inform novel solutions. As a problemsolving framework, Design thinking can be applied in teaching and learning in classroom. It offers a diverse set of adaptable problem-solving and idea generation processes that can help students to learn how to learn and develop a more creative mindset, and foster interdisciplinary exploration.
\end{abstract}

Keywords--- Design Thinking Teaching Learning

\section{BACKGROUND}

Classroom teaching is the learning central of students in colleges and universities, and the main form of students learning. Therefore, to improve the quality of talent training, we must firmly grasp the key of classroom teaching. Teaching is an educational activity composed of teachers' teaching and students' learning. Through teaching, teachers teach the scientific knowledge accumulated by to students purposefully and systematically. However, at the background of Internet era, the way that people learn and communicate has been changed radically, so the way of knowledge teaching and students' cognition of the world has also changed greatly. The teacher is facing new pedagogical challenges in the digital era. So how to reform and innovate the classroom teaching in colleges and universities to meet the needs of talent training is a big problem that we must face.

With the rapid development of artificial intelligence, more and more traditional human resources are gradually replaced by machines. However, the ability to solve complex problems is an important skill that artificial intelligence cannot replace. To solve complex problems, firstly, we need to recognize the essence of the problem, make clear the goal, then analyze the problem, make hypothesis analysis and verification under different conditions, and then put forward the solution to the problem. Therefore, the teachers in the new era should pay more attention to the combination of learning and thinking, learning for teaching, self-thinking, inspiration and guidance, passion display and researchbased learning. At the same time the emphasis of teaching methods should be to teach students how to learn and develop their ability of problem-solving.

\section{A METHODOLOGICAL APPROACH: DESIGN THINKING FOR CREATIVE PROBLEM- SOLVING}

Design thinking is a process that uses the core principles of design to identify innovative solutions, solve problems, and enhance the user experience (Adams \& Nash 2016). The early work related to design thinking started from the Palo Alto based design firm, IDEO, which focused on bringing innovation to their clients in product design. Design thinking is a design methodology that provides a solution-based approach to solving problems. It's extremely useful in tackling complex problems that are ill-defined or unknown, by understanding the human needs involved, by re-framing the problem in human-centric ways, by creating many ideas in brainstorming sessions, and by adopting a hands-on approach in prototyping and testing. Understanding these five stages of Design Thinking will empower anyone to apply the Design Thinking methods in order to solve complex problems that occur around us.
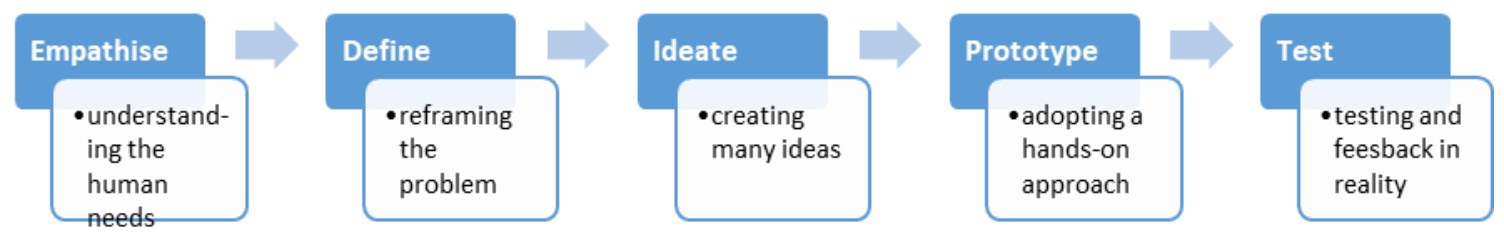

Figure 1: The five stages of Design Thinking

The five stages of Design Thinking are shown in figure 1: Empathize, Define (the problem), Ideate, Prototype, and Test. Design thinking can help students establish the thinking mode of "traditional design thinking mode + visual thinking + social thinking", change the dominant position of teachers in the teaching process, improve students' 
participation in teaching activities, make teachers and students in an equal position, and advocate "personalized" learning. The reform idea of modern teaching method is to use large class teaching method to complete theoretical teaching; use heuristic project teaching method to encourage students to deepen knowledge and explore knowledge application; use participatory teaching method to let students participate in the design and teaching of curriculum projects; use studio teaching to complete the construction of interdisciplinary project learning group; use audio-visual media and communication technology Mutual media means, used to share basic knowledge demonstration teaching video, convenient for students to preview, self-study and review at any time and any place. Innovation oriented teaching method reform needs design thinking. So, applying design thinking in classrooms is adapt to the current teaching method reform and innovation.

\section{THE ROLE OF THE TEACHER IN A CLASSROOM BASED ON DESIGN THINKING}

\section{(1) Facilitator}

The primary responsibility of the teacher is to create a collaborative problem-solving environment where students become active participants in their own learning. From this perspective, a teacher acts as a facilitator of learning rather than an instructor. The teacher needs to understand the students' preexisting conceptions, and guides the activity to express them.

(2) Designer

The lecturer of systematic knowledge system is transformed into the instructional designer oriented by practical problems. Connect the subject knowledge with the sense of practical problems, and integrate them into the classroom through effective design guidance. So that students can feel the problem, and can act effectively.

(3) Co-learner

Although teachers are experts in the field of professional knowledge, but when they are faced with practical problems, their thinking and action will be very limited. So, the teacher should be transformed into student's co-learner. Only in this way they can mobilize the enthusiasm and initiative of students, constantly break through the framework of teachers in classroom teaching.

(3) Observer

Every student has its own characteristics. Our educational goal is to tap and cultivate students' potential, help them establish a positive outlook on life and values, and become useful people in society. Using design thinking to design the classroom, teachers are the common learners of students, which can more effectively observe the characteristics of students, understand their learning state, and their demand for learning resources, and then can better design the classroom. By observing of students' learning, the teacher can find a better way to establish good learning ecology.

\section{THE FEATURES OF A CLASSROOM BASED ON DESIGN THINKING}

As shown in Table 1, classroom based on design thinking has many different features from traditional classroom.

Table 1: Comparison between Traditional Classroom and Classroom based on Design Thinking

\begin{tabular}{|l|l|}
\hline \multicolumn{1}{|c|}{ Traditional Classroom } & \multicolumn{1}{|c|}{ Classroom based on Design Thinking } \\
\hline $\begin{array}{l}\text { Strict adherence to a fixed curriculum is highly } \\
\text { valued. }\end{array}$ & Pursuit of student questions and interests is valued. \\
\hline $\begin{array}{l}\text { Learning is based on repetition. } \\
\text { Teacher-centered. }\end{array}$ & $\begin{array}{l}\text { Learning is interactive, building on what the student already } \\
\text { knows. }\end{array}$ \\
\hline $\begin{array}{l}\text { Teachers disseminate information to students; } \\
\text { students are recipients of knowledge (passive } \\
\text { learning). }\end{array}$ & $\begin{array}{l}\text { Teachers have a dialogue with students, helping students construct } \\
\text { their own knowledge (active learning). }\end{array}$ \\
\hline Teacher's role is directive, rooted in authority. & Teacher's role is interactive, rooted in negotiation. \\
\hline Students work primarily alone (competitive). & Students work primarily in groups (cooperative). \\
\hline
\end{tabular}

There are four basic characteristics of learning environments based on design thinking, which must be considered when implementing design thinking workshop.

(1) Knowledge will be shared between teachers and students. 
(2) Teachers and students will share authority.

(3) The teacher's role looks like a facilitator or guide.

(4) Workshop will consist of small numbers of heterogeneous students.

Over the years, the teaching reform has always emphasized that classroom teaching should be student-oriented, give full play to students' initiative and pay attention to students' learning personality. The core of design thinking is humanoriented, classroom is the main place and way for students to learn, of course, that should be student-oriented. By offering a diverse set of adaptable problem-solving and idea generation processes, teacher can help students to learn how to learn and develop a more creative mindset, and foster interdisciplinary exploration.

\section{REFERENCES}

[1] Adams C, Nash J B . Exploring Design Thinking Practices in Evaluation. 2016.

[2] Beligatamulla G . Design thinking for business and entrepreneurship: accelerating innovation in higher education in Sri Lanka[C]// International Conference on Business Research. 2018.

[3] David, Dunne, Roger, et al. Design Thinking and How It Will Change Management Education: An Interview and Discussion[J]. Academy of Management Learning \& Education, 2006.

[4] Educational Researcher, 28(7), 4-14. https://doi.org/10.3102/0013189X028007004

[5] Fisher W P, Oon P T, Benson S . Applying Design Thinking to systemic problems in educational assessment information management[J]. Journal of Physics Conference, 2018, 1044.

[6] Grubb R, Reich J , Huttner-Loan L, et al. Design Thinking for Leading and Learning in Review. 2017.

[7] Kernbach S , Nabergoj A S . Visual Design Thinking: Understanding the Role of Knowledge Visualization in the Design Thinking Process[C]// International Conference Information Visualisation. IEEE Computer Society, 2018.

[8] Martin, Roger, L. The Design of Business: Why Design Thinking Is the Next Competitive Advantage.[J]. Harvard Business School Press Books, 2009.

[9] Mosley G, Wright N, Wrigley C . Facilitating design thinking: A comparison of design expertise[J]. Thinking Skills \& Creativity, 2018:S1871187117302249.

[10] Schoenfeld, A. (1999). Looking toward the 21st century: Challenges of educational theory and practice.

[11] Taylor J. Combining design thinking and "wordless picturebooks" for discussion of social issues. 2018.

[12] Wong Y L, Wong B . Design Thinking for Education[M]. 2019.

[13] XinKai Yang, Thinking and Exploration of Curriculum Teaching Based on Design Thinking Framework[J]. Advances in Education, 2017, 007(006):P.376-380. 